\title{
PARTISIPASI MASYARAKAT DALAM PENDIDIKAN
}

\author{
Oleh: Normina \\ Dosen pada Sekolah Tinggi Agama Islam Al-Washliyah Barabai
}

\begin{abstract}
Absrtak
Partisipasi masyarakat dengan lembaga pendidikan merupakan seluruh proses kegiatan yang direncanakan dan diusahakan secara sengaja dan bersungguh-sungguh, disertai pembinaan secara kontinu untuk mendapatkan simpati dari masyarakat pada umumnya. Khususnya masyarakat yang berkepentingan langsung dengan pendidikan. Simpati masyarakat akan tumbuh melalui upayaupaya sekolah dalam menjalin hubungan secara insentif dan proaktif di samping membangun citra lembaga pendidikan yang baik. Partisipasi adalah keterlibatan aktif dari seseorang, atau sekelompok orang (masyarakat) secara sadar untuk berkontribusi secara sukarela dalam program pembangunan dan terlibat mulai dari perencanaan, pelaksanaan, monitoring sampai pada tahap evaluasi.
\end{abstract}

Kata Kunci: Partisipasi, Masyarakat, Pendidikan.

\section{A. Pendahuluan}

Pendidikan tidak bisa lahir tanpa adanya kemunculan sebuah komunitas atau masyarakat. Pendidikan dilakukan bertujuan bagi kemajuan, perubahan, dan stabilitas sosial dari masyarakat. Pendidikan dilakukan tidak lain untuk kepentingan sebuah masyarakat, baik di tingkat lokal, keluarga, daerah, provinsi, dan bangsa secara keseluruhan.

Pendidikan menengahi masyarakat atau hubungan pendidikan dengan masyarakat. Harus disadari bahwa masyarakat memiliki peranan yang sangat penting terhadap keberadaan, kelangsungan, bahkan kemajuan pendidikan. Setidaknya salah satu parameter penentu nasib pendidikan adalah masyarakat. Bila ada pendidikan yang maju, hampir bisa dipastikan salah satu faktor keberhasilan tersebut adalah keterlibatan dan partisipasi masyarakat yang maksimal. Begitu pula sebaliknya, bila ada pendidikan yang bernasib memprihatinkan, salah satu penyebabnya bisa jadi karena masyarakat enggan mendukung.
Kepercayaan masyarakat salah satu kunci kemajuan lembaga pendidikan. Ketika masyarakat memiliki kepercayaan terhadap lembaga pendidikan mereka akan mendukung penuh terhadap jalannya pendidikan itu. Oleh karena itu, masyarakat merupakan komponen strategis yang harus mendapat perhatian penuh oleh pendidikan.

Masyarakat memiliki posisi ganda, yaitu sebagai objek dan sebagai subjek yang keduanya memiliki makna fungsional bagi pengelolaan lembaga pendidikan. Ketika lembaga pendidikan sedang melakukan promosi penerimaan calon siswa baru, maka masyarakat merupakan objek yang mutlak dibutuhkan. Sementara itu, respons masyarakat terhadap promosi itu menempatkan mereka sebagai subjek yang memiliki kewenangan penuh untuk menerima atau menolaknya. Posisi masyarakat sebagai subjek juga terjadi ketika mereka menjadi pengguna lulusan lembaga pendidikan. Oleh karena itu, partisipasi dan hubungan yang baik dengan masyarakat harus dikelola dengan baik. 
Partisipasi masyarakat dengan lembaga pendidikan merupakan seluruh proses kegiatan yang direncanakan dan diusahakan secara sengaja dan bersungguh-sungguh, disertai pembinaan secara kontinu untuk mendapatkan simpati dari masyarakat pada umumnya. Khususnya masyarakat yang berkepentingan langsung dengan pendidikan. Simpati masyarakat akan tumbuh melalui upaya-upaya sekolah dalam menjalin hubungan secara insentif dan proaktif di samping membangun citra lembaga pendidikan yang baik.

\section{B. Partisipasi Masyarakat}

Kata "partisipasi masyarakat" dalam pembangunan menunjukkan pengertian pada keikutsertaan pembangunan (United Nation, 1975). Partisipasi masyarakat dalam pengembangan pendidikan Indonesia, perlu ditumbuhkan adanya kemauan dan kemampuan warga atau kelompok masyarakat untuk berpartisipasi dalam pengembangan pendidikan . Sebaliknya pihak pemerintah atau Negara juga memberikan ruang atau kesempatan kepada warga atau kelompok masyarakat untuk berpartisipasi seluas mungkin sehingga kita bisa mencetuskan sebuah ide yang kreatif dan imajinatif dalam pengembangan pendidikan, seperti pepatah orang Jawa "Rawe-rawe rantas, malang-malang putung'" atau dalam Bahasa Indonesianya Bercerai kita runtuh, Bersatu kita teguh"

Menurut Ach. Wazir Ws., et al. (1999; 29) partisipasi bisa diartikan sebagai keterlibatan seseorang secara sadar ke dalam interaksi sosial dalam situasi tertentu. Dengan pengertian itu, seseorang bisa berpartisipasi bila ia menemukan dirinya dengan atau dalam kelompok, melalui berbagai proses berbagi dengan orang lain dalam hal nilai, tradisi, perasaan, kesetiaan, kepatuhan dan tanggungjawab bersama.
Partisipasi masyarakat menurut Isbandi (2007; 27) adalah keikutsertaan masyarakat dalam proses pengidentifikasian masalah dan potensi yang ada di masyarakat, pemilihan dan pengambilan keputusan tentang alternatif solusi untuk menangani masalah, pelaksanaan upaya mengatasi masalah, dan keterlibatan masyarakat dalam proses mengevaluasi perubahan yang terjadi.

Mikkelsen (1999; 64) membagi partisipasi menjadi 6 (enam) pengertian, yaitu:

1. Partisipasi adalah kontribusi sukarela dari masyarakat kepada proyek tanpa ikut serta dalam pengambilan keputusan;

2. Partisipasi adalah "pemekaan" (membuat peka) pihak masyarakat untuk meningkatkan kemauan menerima dan kemampuan untuk menanggapi proyekproyek pembangunan;

3. Partisipasi adalah keterlibatan sukarela oleh masyarakat dalam perubahan yang ditentukannya sendiri;

4. Partisipasi adalah suatu proses yang aktif, yang mengandung arti bahwa orang atau kelompok yang terkait, mengambil inisiatif dan menggunakan kebebasannya untuk melakukan hal itu;

5. Partisipasi adalah pemantapan dialog antara masyarakat setempat dengan para staf yang melakukan persiapan, pelaksanaan, monitoring proyek, agar supaya memperoleh informasi mengenai konteks lokal, dan dampak-dampak sosial;

6. Partisipasi adalah keterlibatan masyarakat dalam pembangunan diri, kehidupan, dan lingkungan mereka.

Pentingnya partisipasi dikemukakan oleh Conyers (1991; 154-155) sebagai berikut: pertama, partisipasi masyarakat merupakan suatu alat guna memperoleh informasi mengenai kondisi, kebutuhan, dan sikap masyarakat setempat, yang tanpa kehadirannya program pembangunan serta proyek-proyek akan gagal; kedua, bahwa masyarakat akan lebih memper- 
cayai proyek atau program pembangunan jika merasa dilibatkan dalam proses persiapan dan perencanaannya, karena mereka akan lebih mengetahui seluk-beluk proyek tersebut dan akan mempunyai rasa memiliki terhadap proyek tersebut; ketiga, bahwa merupakan suatu hak demokrasi bila masyarakat dilibatkan dalam pembangunan masyarakat mereka sendiri.

Apa yang ingin dicapai dengan adanya partisipasi adalah meningkatnya kemampuan (pemberdayaan) setiap orang yang terlibat baik langsung maupun tidak langsung dalam sebuah program pembangunan dengan cara melibatkan mereka dalam pengambilan keputusan dan kegiatan-kegiatan selanjutnya dan untuk jangka yang lebih panjang. Adapun prinsip-prinsip partisipasi tersebut, sebagaimana tertuang dalam Panduan Pelaksanaan Pendekatan Partisipatif yang disusun oleh Department for International Development (DFID) (dalam Monique Sumampouw, 2004; 106-107) adalah:

1. Cakupan. Semua orang atau wakil-wakil dari semua kelompok yang terkena dampak dari hasil-hasil suatu keputusan atau proses proyek pembangunan.

2. Kesetaraan dan kemitraan (Equal Partnership). Pada dasarnya setiap orang mempunyai keterampilan, kemampuan dan prakarsa serta mempunyai hak untuk menggunakan prakarsa tersebut terlibat dalam setiap proses guna membangun dialog tanpa memperhitungkan jenjang dan struktur masing-masing pihak.

3. Transparansi. Semua pihak harus dapat menumbuhkembangkan komunikasi dan iklim berkomunikasi terbuka dan kondusif sehingga menimbulkan dialog.

4. Kesetaraan kewenangan (Sharing Power/ Equal Power Ship). Berbagai pihak yang terlibat harus dapat menyeimbangkan distribusi kewenangan dan kekuasaan untuk menghindari terjadinya dominasi.
5. Kesetaraan Tanggung Jawab (Sharing Responsibility). Berbagai pihak mempunyai tanggung jawab yang jelas dalam setiap proses karena adanya kesetaraan kewenangan (sharing power) dan keterlibatannya dalam proses pengambilan keputusan dan langkah-langkah selanjutnya.

6. Pemberdayaan (Empowerment). Keterlibatan berbagai pihak tidak lepas dari segala kekuatan dan kelemahan yang dimiliki setiap pihak, sehingga melalui keterlibatan aktif dalam setiap proses kegiatan, terjadi suatu proses saling belajar dan saling memberdayakan satu sama lain.

7. Kerjasama. Diperlukan adanya kerja sama berbagai pihak yang terlibat untuk saling berbagi kelebihan guna mengurangi berbagai kelemahan yang ada, khususnya yang berkaitan dengan kemampuan sumber daya manusia.

Dari definisi partisipasi di atas, dapat dibuat kesimpulan bahwa partisipasi adalah keterlibatan aktif dari seseorang, atau sekelompok orang (masyarakat) secara sadar untuk berkontribusi secara sukarela dalam program pembangunan dan terlibat mulai dari perencanaan, pelaksanaan, monitoring sampai pada tahap evaluasi.

Partisipasi masyarakat dalam pendidikan dapat diwujudkan dalam berbagai bentuk:

\section{Partisipasi finansial}

Berupa dukungan dana sesuai dengan kekuatan dan kemampuan masyarakat. Termasuk juga orangtua secara kolektif dapat mendukung dana yang diperlukan sekolah, yang benar-benar dapat dipertanggungjawabkan untuk keberhasilan pendidikan. Selain itu, lembaga bisnis dan industri diharapkan dapat menyisihkan anggaran untuk pemberian beasiswa pendidikan. 


\section{Partisipasi material}

Diwujudkan dengan sumbangan bahanbahan yang berkenaan dengan material bangunan, untuk penyempurnaan bangunan ruang dan tempat untuk kegiatan belajar agar kegiatan belajar mengajar dapat berjalan dengan baik. Demikian juga masyarakat mendukung terciptanya lingkungan fisik yang kondusif untuk kegiatan belajar mengajar.

\section{Partisipasi akademik}

Kepedulian masyarakat terhadap penyelenggaraan kegiatan akademik yang lebih berkualitas. Dukungan dapat diwujudkan dengan dukungan orangtua dan masyarakat untuk mengawasi dan membimbing belajar anak di rumah. Selain itu banyak lembagalembaga pemerintahan maupun non pemerintahan yang dapat memberikan kesempatan untuk praktik atau magang. Hal ini dilakukan untuk memberikan wawasan secara nyata kepada peserta didik.

\section{Partisipasi kultural}

Perhatian masyarakat terhadap terpeliharanya nilai kultural dan moral yang terdapat di lingkungan sekitar sekolah sehingga sekolah mampu menyesuaikan diri dengan budaya setempat.

\section{Partisipasi evaluatif}

Keterlibatan masyarakat dalam melakukan pengendalian dan kontrol terhadap penyelenggaraan pendidikan, sehingga masyarakat dapat memberikan umpan balik dan penilaian terhadap kinerja lembaga pendidikan. Selain itu, masyarakat juga dapat berperan dalam penyusunan atau pemberi masukan dalam penyusunan kurikulum bagi sekolah. Agar kurikulum itu sesuai dengan kebutuhan siswa.

\section{Pengelolaan Partisipasi Masyarakat dalam Pendidikan}

diawali dengelolaan partisipasi masyarakat implementasi, monitoring dan evaluasi. Tahap perencanaan dilakukan terhadap kebutuhan baik lembaga pendidikan maupun masyarakat, selanjutnya membuat perencanaan berdasarkan atas kebutuhan yang diperlukan untuk mengetahui potensi-potensi yang dimiliki menyusun alternatif program kegiatan. Kegiatan yang bermanfaat yang menunjang pendidikan, misalnya dengan ilmu pengetahuan dan teknologi, nilai-nilai spiritualitas keagamaan, identifikasi kebutuhan masyarakat dapat dilihat mereka memilih lembaga pendidikan, yang pada dasarnya oleh alasan teologis, akademik, sosiologi, filosofi dan ekonomi.

Berdasarkan kebutuhan masyarakat tersebut kedua lembaga ini berusaha meresponnya dengan memberikan pelayanan maksimal dan bersama-sama dengan masyarakat melalui wadah komite sekolah melakukan inovasi sesuai dengan tuntutan masyarakat.

Pada tahap implementasi disusunlah cara/kiat yang dilakukan dengan kecermatan, kejelian khusus keseriusan dari semua pihak para pengelola. Di antara implementasi pelaksanaan partisipasi masyarakat adalah tercerminnya kerja sama yang baik antara kepala sekolah, guru dan majelis madrasah/ komite dan masyarakat umum. Kepala sekolah bersama dewan guru dan karyawan melaksanakan program pendidikan, sementara masyarakat mem-back up kegiatan tersebut. Majelis sekolah sebagai mitra kerja ikut berpartisipasi dalam menyusun dan melaksanakan program, partisipasi dalam menghimpun sumber-sumber daya dan dana, melakukan hubungan kerja sama dengan masyarakat, LSM dan instansi pemerintah dan non pemerintah serta perguruan tinggi dan akademisi. 
Pada tahap pemantauan (monitoring) dan evaluasi dilakukan pada saat berlangsungnya dan setelah kegiatan yang bertujuan untuk melihat dan mengkaji progress keberhasilan program dan memberikan feedback terhadap pelaksana kegiatan. Pada tahap ini dilakukan pengawasan dan akuntabilitas pelaksanaan kegiatan. Pada saat ini pertanggungjawaban bisa dilakukan dengan melalui berbagai pertemuan dan rapat dengan BP3 atau masyarakat dan membeberkan secara terbuka semua persoalan sekolah. Persoalan yang diaudit dan dipertanggungjawabkan sekolah kepada masyarakat adalah: kinerja guru, perilaku guru, pelaksanaan rencana sekolah, kesejahteraan guru, pelaksanaan pembelajaran, kekurangan tenaga pengajar, keadaan fisik gedung, keuangan sekolah, keuangan BP3/majelis sekolah.

Ada beberapa hal yang dapat dilakukan sekolah atau lembaga pendidikan agar partisipasi masyarakat dalam dunia pendidikan semakin baik, antara lain:

\section{Menjalin Komunikasi yang Efektif dengan Orang Tua dan Masyarakat.}

Partisipasi orang tua dan masyarakat akan tumbuh jika orang tua dan masyarakat juga merasakan manfaat dari keikutsertaannya dalam program sekolah. Manfaat dapat diartikan luas, termasuk rasa diperhatikan dan rasa puas karena dapat menyumbangkan kemampuannya bagi kepentingan sekolah. Jadi prinsip menumbuhkan hubungan dengan masyarakat adalah saling memberikan kepuasan. Salah satu jalan penting untuk membina hubungan dengan masyarakat adalah menetapkan komunikasi yang efektif.

\section{Melibatkan Masyarakat dan Orang Tua dalam Program Sekolah}

Di sini sekolah harus memperkenalkan program dan kegiatan sekolah kepada masya- rakat. Agar masyarakat lebih mengenal dan dapat membantu program tersebut. Selain itu, hal ini dilakukan agar hubungan masyarakat dan sekolah menjadi erat. Diharapkan juga masyarakat dan sekolah mengadakan kerjasama dalam hari-hari besar agama. Selain itu juga, sekolah perlu memberi tahu masyarakat tentang program unggulan sekolah agar menarik minat masyarakat.

3. Mengundang masyarakat dalam rapat tahunan sekolah

Masyarakat perlu terus melakukan pemantauan dan evaluasi terhadap penyelenggaraan pendidikan. Dalam hal ini tentu sekolah harus transparan dalam hal kurikulum pembelajaran sekolah dan juga tentang biaya penyelenggaraan sekolah. Hal ini dimaksudkan agar orang tua tidak hanya menerima informasi dari sekolah. Tetapi masyarakat juga bisa memberikan informasi yang berkaitan dengan peserta didik agar pendidikan dapat berjalan dengan lancar. Selain itu, sekolah juga dapat melibatkan masyarakat dalam pengambilan keputusan yang berkenaan dengan kebutuhan operasional maupun non operasional sekolah. Di forum ini masyarakat dan sekolah saling bertukar pikiran, mengeluarkan ide atau gagasan dan juga menyampaikan permasalahan yang dihadapi baik oleh orang tua murid ataupun sekolah. Jadi sekolah dan masyarakat dapat saling bahu-membahu dalam mengembangkan pendidikan.

Dalam Peraturan Pemerintah No. 39 Tahun 1992 Bab III pasal 4 peran serta/partisipasi masyarakat dapat berbentuk:

1. Pendirian dan penyelenggaraan satuan pendidikan pada jalur pendidikan sekolah atau jalur pendidikan luar sekolah, pada semua jenis pendidikan kecuali pendidikan kedinasan, dan pada semua jenjang pendidikan di jalur pendidikan sekolah; 
2. Pengadaan dan pemberian bantuan tenaga kependidikan untuk melaksanakan atau membantu melaksanakan pengajaran, pembimbingan dan/atau pelatihan peserta didik;

3. Pengadaan dan pemberian bantuan tenaga ahli untuk membantu pelaksanaan kegiatan belajar-mengajar dan/atau penelitian dan pengembangan;

4. Pengadaan dan/atau penyelenggaraan program pendidikan yang belum diadakan dan/atau diselenggarakan oleh Pemerintah untuk menunjang pendidikan nasional;

5. Pengadaan dana dan pemberian bantuan yang dapat berupa wakaf, hibah, sumbangan, pinjaman, beasiswa, dan bentuk lain yang sejenis;

6. Pengadaan dan pemberian bantuan ruangan, gedung, dan tanah untuk melaksanakan Pengadaan dan pemberian bantuan buku pelajaran dan peralatan pendidikan untuk melaksanakan kegiatan belajar-mengajar;

7. Pemberian kesempatan untuk magang dan/atau latihan kerja;

8. Pemberian bantuan manajemen bagi penyelenggaraan satuan pendidikan dan pengembangan pendidikan nasional;

9. Pemberian pemikiran dan pertimbangan berkenaan dengan penentuan kebijaksanaan dan/atau penyelenggaraan pengembangan pendidikan;

10. Pemberian bantuan dan kerjasama dalam kegiatan penelitian dan pengembangan;

11. Keikutsertaan dalam program pendidikan dan/atau penelitian yang diselenggarakan oleh Pemerintah di dalam dan/atau di luar negeri.

\section{Faktor-faktor Pendukung dan Penghambat Partisipasi Masyarakat dalam Pendidikan}

Masyarakat pada dasarnya cenderung berpartisipasi dalam pembangunan pendidikan, tetapi di sisi lain tidak mudah untuk mengajak masyarakat berpartisipasi. Hambatan yang dialami oleh sekolah untuk mengajak partisipasi masyarakat dalam perbaikan mutu pendidikan membuktikan, belum sepenuhnya disadari sebagai tanggung jawab bersama. Realitas tersebut menguatkan asumsi sepenuhnya bahwa partisipasi tidak mudah diwujudkan, karena ada hambatan yang bersumber dari pemerintah dan masyarakat.

Dari pihak pemerintah, faktor yang menghambat partisipasi masyarakat dalam pendidikan dapat berupa:

1. Lemahnya komitmen politik para pengambil keputusan di daerah untuk secara sungguh-sungguh melibatkan masyarakat dalam pengambilan keputusan yang menyangkut pelayanan publik.

2. Lemahnya dukungan SDM yang dapat diandalkan untuk mengimplementasikan strategi peningkatan partisipasi masyarakat dalam pelayanan publik.

3. Rendahnya kemampuan lembaga legislative dalam mengaktualisasikan kepentingan masyarakat.

4. Lemahnya dukungan anggaran, karena kegiatan partisipasi public sering kali hanya dilihat sebagai proyek, maka pemerintah tidak menjalankan dana secara berkelanjutan.

Sedangkan dari pihak masyarakat, faktor penghambat partisipasi dalam pendidikan muncul karena beberapa hal, antara lain:

1. Budaya paternalism yang dianut oleh masyarakat menyulitkan untuk melakukan diskusi secara terbuka.

2. Apatisme karena selama ini masyarakat jarang dilibatkan dalam pembuatan keputusan oleh pemerintah daerah.

3. Tidak adanya kepercayaan masyarakat kepada pemerintah.

4. Hambatan kultural, yaitu masih adanya sebagian masyarakat yang menganggap bahwa pendidikan formal bertentangan dengan adat mereka, misalnya saja pada masyarakat Samin yang menganggap 
bahwa orang yang pintar hanya akan membuat orang membodohi orang lain.

5. Hambatan geografis, misalnya jauhnya lokasi sekolah yang diikuti oleh tidak adanya fasilitas transportasi dan akses jalan yang mendukung untuk mencapai sekolah.

6. Mahalnya biaya pendidikan, terutama pada pendidikan tingkat atas dan perguruan tinggi.

Faktor yang mendorong partisipasi masyarakat dalam pendidikan, antara lain:

1. Pola pikir masyarakat yang semakin maju yang menganggap pendidikan sangat penting dan menganggap pendidikan sebagai salah satu jalan untuk memudahkan mereka dalam mencari pekerjaan.

2. Adanya stratifikasi sosial yang menempatkan tingkat pendidikan tertentu sebagai sebuah prestise dan salah satu penentu status sosial pada suatu masyarakat.

3. Pandangan masyarakat bahwa pendidikan sebagai salah satu cara untuk merubah nasib menjadi lebih baik.

4. Fasilitas dan akses menuju sarana pendidikan yang memadai, misalnya saja sudah banyak sekolah yang berada di pelosok desa yang mudah dijangkau oleh masyarakat yang tinggal di daerah terpencil.

5. Sosialisasi tentang pentingnya pendidikan yang terus dilakukan untuk meningkatkan derajat kehidupan masyarakat.

6. Adanya program wajib belajar 9 tahun dari pemerintah.

7. Adanya sekolah kejuruan yang membentuk siswa siap kerja setelah lulus, dan siswa juga bisa melanjutkan pendidikan ke perguruan tinggi.

8. Program Biaya Operasional Sekolah (BOS), yang membantu meringankan biaya pendidikan pada tingkat pendidikan mulai dari sekolah dasar hingga sekolah menengah pertama.

9. Pemerataan kesempatan untuk memperoleh pendidikan sehingga semua lapisan masyarakat sekarang ini sudah bisa mengakses pendidikan, bukan hanya dari golongan masyarakat saja yang bisa mengakses pendidikan. Pemerataan pendidikan diharapkan dapat memberikan kesempatan yang sama dalam memperoleh pendidikan bagi semua usia sekolah. Strategi ini perlu mendapat prioritas karena ternyata banyak anak-anak di Indonesia, terutama di pedesaan masih banyak yang belum mengenyam pendidikan, terutama di tingkat SLTP. Pemerataan kesempatan berarti setiap warga negara memiliki kesempatan yang sama untuk memperoleh pendidikan sebagaimana diamanatkan dalam UUD 1945 pasal 31 yang berbunyi" Tiap-tiap warga negara berhak mendapat pengajaran". Begitu pula dalam UU No. 20 Tahun 2003 tentang Sistem Pendidikan Nasional yang tidak membedakan warga negara menurut jenis kelamin, status sosial ekonomi, agama, dan lokasi geografis.

10. Aksebilitas artinya setiap orang tanpa membedakan asal usulnya memiliki akses (kesempatan masuk) yang sama ke dalam pendidikan pada semua jenis, jenjang, maupun jalur pendidikan. Adapun yang dimaksud dengan keadilan di sini adalah perbedaan perlakuan pada peserta didik sesuai dengan kondisi internal dan eksternal. Secara moral-etis adalah adil dan wajar apabila peserta didik diperlakukan menurut kemampuan, bakat dan minatnya.

11. Persepsi orangtua tentang pendidikan, Persepsi orangtua terhadap pendidikan akan mempengaruhi aspirasi. Artinya, kemampuan orangtua dalam melihat pentingnya pendidikan akan berpengaruh pada harapan dan tujuan untuk keberhasilan pada masa yang akan datang. Yang dimaksud aspirasi di sini adalah keinginan, harapan, atau citacita orangtua terhadap tingkat pencapaian pendidikan anak-anaknya. 
Faktor yang mempengaruhi partisipasi masyarakat dalam suatu program juga dapat berasal dari unsur luar/lingkungan. Menurut Holil $(1980 ; 10)$ ada 4 poin yang dapat mempengaruhi partisipasi masyarakat yang berasal dari luar/lingkungan, yaitu:

1. Komunikasi yang intensif antara sesama warga masyarakat, antara warga masyarakat dengan pimpinannya serta antara sistem sosial di dalam masyarakat dengan sistem di luarnya;

2. Iklim sosial, ekonomi, politik dan budaya, baik dalam kehidupan keluarga, pergaulan, permainan, sekolah maupun masyarakat dan bangsa yang menguntungkan bagi serta mendorong tumbuh dan berkembangnya partisipasi masyarakat;

3. Kesempatan untuk berpartisipasi. Keadaan lingkungan serta proses dan struktur sosial, sistem nilai dan norma-norma yang memungkinkan dan mendorong terjadinya partisipasi sosial;

4. Kebebasan untuk berprakarsa dan berkreasi. Lingkungan di dalam keluarga masyarakat atau lingkungan politik, sosial, budaya yang memungkinkan dan mendorong timbul dan berkembangnya prakarsa, gagasan, perseorangan atau kelompok.

Partisipasi adalah proses aktif dan inisiatif yang muncul dari masyarakat serta akan terwujud sebagai suatu kegiatan nyata apabila terpenuhi oleh tiga faktor pendukungnya, yaitu:

\section{Kemauan dan kemampuan berpartisipa- si berasal dari masyarakat itu sendiri}

Kemauan dan kemampuan berpartisipasi berasal dari masyarakat itu sendiri, sedangkan kesempatan berasal dari pihak luar. Peran serta masyarakat dalam dunia pendidikan sangat penting. Keharusan masyarakat terlibat dalam pendidikan sudah menjadi peraturan UU No. 2 tahun 1989 yaitu sumber daya pendidikan adalah dukungan dan penunjang pelaksanaan pendidikan yang terwujud sebagai tenaga, dana, sarana da prasarana yang tersedia yang digunakan dan didayagunakan oleh keluarga, sekolah dan masyarakat, peserta didik dan pemerintah secara bersama-sama. Ada tidaknya kemauan keluarga/warga masyarakat dalam pengembangan pendidikan terkait dengan paradigma pembangunan di Indonesia. Agar kemampuan berpartisipasi dimiliki oleh masyarakat maka perlu peningkatan sumber daya manusia dengan cara memperluas tiga jenis pendidikan di masyarakat baik formal, nonformal, maupun informal. Kaitan masyarakat dan pendidikan dapat ditinjau dari tiga segi yaitu:

a. Masyarakat sebagai penyelenggara pendidikan baik dilembagakan maupun tidak dilembagakan

b. Lembaga-lembaga masyarakat atau kelompok sosial masyarakat baik langsung mau pun tidak langsung mempunyai peranan dan fungsi edukatif.

c. Dalam masyarakat tersedia berbagai sumber belajar, baik yang dirancang maupun tidak dirancang dan dimanfaatkan.

\section{Fungsi masyarakat sebagai pusat pendidikan}

Fungsi masyarakat sebagai pusat pendidikan sangat bergantung pada taraf perkembangan dari masyarakat dan sumber-sumber belajar yang tersedia di dalamnya. Karena secara garis besar masyarakat dibedakan beberapa tipe, yaitu:

a. Tipe masyarakat dengan sistem berkebun yang amat sederhana desa terpencil

b. Tipe masyarakat pedesaan

c. Tipe masyarakat perkotaan

Selain itu, juga terdapat sejumlah lembaga kemasyarakatan yang mempunyai peranan dan fungsi edukatif yang besar adalah kelompok sebaya, organisasi kepemudaan, organisasi keagamaan, ekonomi, politik, kebu- 
dayaan, media massa, dan sebagainya. Kemampuan tersebut bukan hanya memberikan kontribusi sosialisasi tetapi juga pengetahuan dan keterampilan.

Setelah keluarga, kelompok sebaya mungkin paling besar pengaruhnya terhadap pembentukan kepribadian, terutama pada saat anak berusaha melepaskan diri dari pengaruh kekuasaan orang tua. Kelompok sebaya adalah suatu kelompok yang terdiri dari orang-orang yang bersamaan usianya. Adapun fungsi kelompok teman sebaya adalah:

a. Mengajar berhubungan dan menyesuaikan diri dengan orang lain.

b. Memperkenalkan kehidupan masyarakat yang lebih luar.

c. Menguatkan sebahagian dari nilai-nilai yang berlaku dalam kehidupan masyarakat.

d. Memberikan pengalaman dan memperkenalkan tentang persamaan hak.

e. Memberikan pengetahuan yang tidak didapatkan di dalam keluarga.

\section{Masalah Pendidikan di Indonesia}

Secara singkat pendidikan merupakan produk dari masyarakat. Pendidikan tidak lain merupakan proses transmisi pengetahuan, sikap, kepercayaan, keterampilan dan aspekaspek perilaku lainnya kepada generasi ke generasi. Bagi masyarakat pendidikan diharapkan mampu menunjang kelangsungan dan proses kemajuan hidupnya. Agar masyarakat dapat melangsungkan hidupnya dan eksistensinya yang memiliki nilai-nilai, pengetahuan, serta keterampilan.

Aktivitas pendidikan telah dimulai semenjak seorang individu pertama kali berinteraksi dengan lingkungan eksternal. Sehingga pendidikan menjadi bagian yang tak terpisahkan dari kehidupan sosial budaya dan masyarakat. Adapun masalah pokok pendidikan di Indonesia adalah: a. Masalah pemerataan pendidikan. Masalah pemerataan pendidikan adalah persoalan bagaimana sistem pendidikan dapat menyediakan kesempatan yang seluasluasnya bagi seluruh warga negara untuk memperoleh pendidikan.

b. Masalah mutu pendidikan

c. Masalah efesiensi pendidikan mempersoalkan bagaimana suatu sistem pendidikan mendayagunakan sumber daya yang ada untuk mencapai tujuan pendidikan

d. Masalah relevansi pendidikan.

\section{E. Peran serta Masyarakat dalam Pendidikan}

Demokratisasi penyelenggaraan pendidikan, harus mendorong pemberdayaan masyarakat dengan memperluas partisipasi masyarakat dalam pendidikan yang meliputi peran serta perorangan, kelompok, keluarga, organisasi profesi dan organisasi kemasyarakatan dalam penyelenggaraan dan pengendalian mutu pelayanan pendidikan (pasal 54 ayat 1). Masyarakat tersebut dapat berperan sebagai sumber, pelaksana, dan pengguna hasil pendidikan (pasal 54 ayat 2). Oleh karena itu, masyarakat berhak menyelenggarakan pendidikan yang berbasis masyarakat, dengan mengembangkan dan melaksanakan kurikulum dan evaluasi pendidikan, serta manajemen dan pendanaannya sesuai dengan standar nasional pendidikan (pasal 55 ayat 1 dan 2).

Dana pendidikan yang berbasis masyarakat dapat bersumber dari penyelenggaraan, masyarakat, pemerintah (pusat), pemerintah daerah dan sumber lainnya (pasal 55 ayat 3 ). Demikian juga, lembaga pendidikan yang berbasis masyarakat dapat memperoleh bantuan teknis, subsidi dana, dan sumber daya lain secara adil merata dari pemerintah pusat dan daerah (Hasan Basri, 2012; 92).

Partisipasi masyarakat tersebut kemudian dilembagakan dalam bentuk dewan pendidikan dan komite sekolah. Dewan 
pendidikan adalah lembaga mandiri yang beranggotakan berbagai unsur masyarakat yang peduli terhadap pendidikan. Adapun komite sekolah/madrasah adalah lembaga mandiri yang terdiri dari atas unsur orangtua/ wali peserta didik, komunitas sekolah, serta tokoh masyarakat yang peduli pendidikan (pasal 1 butir 24 dan 25). Dewan pendidikan berperan dalam peningkatan mutu pelayanan pendidikan, dengan memberikan pertimbangan, arahan, dan dukungan tenaga, sarana dan prasarana, serta pengawasan pendidikan pada tingkat nasional, provinsi, dan kabupaten/kota yang tidak mempunyai hubungan kierarkis (pasal 56 ayat 2). Peningkatan mutu pelayanan di tingkat satuan pendidikan peran tersebut menjadi tanggung jawab komite sekolah/ madrasah (pasal 56 ayat 3) (Hasan Basri, 2012; 92).

Pergeseran paradigma pembangunan yang sentralistik ke disentralistik telah mengubah cara pandang penyelenggara negara dan masyarakat dalam penyelenggaraan pembangunan. Pembangunan harus dipandang sebagai bagian dari kebutuhan masyarakat itu sendiri dan bukan semata kepentingan negara. Pembangunan seharusnya mengandung arti bahwa manusia ditempatkan pada posisi perilaku dan sekaligus penerima manfaat dari proses mencari solusi dan meraih hasil pembangunan. Penguatan masyarakat secara institusional bisa diartikan sebagai pengelompokkan anggota masyarakat sebagai warga negara mandiri yang dapat dengan bebas dan egaliter bertindak aktif dalam wacana dan praktis mengenai segala hal yang berkaitan dengan masalah kemasyarakatan dan umumnya.

Peran pemerintah sangat dominan dan peran masyarakat merupakan kewajiban. Penguatan partisipasi masyarakat haruslah menjadi agenda pembangunan itu sendiri, terlebih dalam era globalisasi saat sekarang ini. Peran serta masyarakat harus lebih dimaknai sebagai hak masyarakat untuk ikut mengontrol agenda dan urutan prioritas pembangunan untuk dirinya atau kelompoknya. Oleh karena itu tidak akan dapat diterima jika ada kelompok mendikte dan kepentingannya dalam isi dan prioritas keputusan pembangunan. Titik pusat perhatian adalah ke arah pembangunan yang lebih berpihak kepada masyarakat. Individu bukanlah sebagai objek melainkan sebagai subjek atau pelaku yang menentukan, mengontrol sumber daya, dan mengarahkan proses yang mempengaruhi kehidupannya sendiri. Pembangunan yang memihak rakyat menekankan kepada pentingnya prakarsa dan perbedaan lokal.

Penyadaran diri masyarakat merupakan satu di antara argumen-argumen yang paling penting. Kesempitan pandangan cakrawala rakyat diubah ke arah suatu keinsyafan, perasaan, pemikiran, dan gagasan bahwa akan ada alternatif-alternatif jika dirinya terlibat langsung menyelesaikan masalah-masalahnya. Bentuk aktualisasi dan pernyataan penyadaran diri masyarakat secara kolektif dapat berupa partisipasinya dalam proses pengambilan keputusan yang berhubungan dengan kebutuhan dirinya dan kelompoknya dalam komunitas yang melingkupinya.

Musyawarah adalah merupakan pendekatan kultural khas Indonesia yang dapat dimasukkan dalam proses eksplorasi kebutuhan dan identifikasi masalah. Musyawarah juga merupakan bentuk sarana untuk meningkatkan partisipasinya dan rasa memiliki atas keputusan dan rencana pembangunan. Musyawarah dapat merupakan cara analisis kebutuhan dan tidak sekedar keinginan yang bersifat superfisial demi pemenuhan kebutuhan sesaat. Langkah lain dalam proses partisipasi masyarakat adalah pembentukan kelompok. Melalui kelompok akan dibina solidaritas, kerjasama, musyawarah, rasa aman dan percaya kepada diri sendiri. Salah satu cara yang efektif mem- 
bentuk kelompok adalah melalui pendekatan kepentingan yang secara primordial.

Pembentukan dan pengembangan kelompok masyarakat dapat dikatakan sebagai basis dan strategi pembangunan dari bawah. Dari kelompok-kelompok itu diharapkan akan timbul dinamika dari bawah. Pada dasarnya, partisipasi masyarakat telah terjadi di sekolah dalam praktik penyelenggaraan musyawarah maupun pembentukan institusi lokal. Programprogram sekolah berupa desain kurikulum dan pelaksanaannya kegiatan-kegiatan kurikuler nonkurikuler sampai pada pengadaan kebutuhan sumber daya untuk suatu sekolah agar dapat berjalan lancar, tampaknya harus sudah mulai diberikan ruang partisipasi bagi pihak-pihak yang berkepentingan.

Cara untuk menyalurkan partisipasi dapat diciptakan dengan berbagai variasi cara sesuai dengan kondisi masing-masing wilayah atau komunitas tempat masyarakat dan lembaga pendidikan itu berada. Kondisi ini menuntun kesigapan para pemegang kebijakan dan manajer pendidikan untuk mendistribusikan peran dan kekuasaannya agar bisa menampung sumbangan partisipasi masyarakat.

Peranan pendidikan bagi masyarakat secara luas bisa dilihat dari bagaimana kiprah, peranan, sikap, dan sumbangsih kalangan pendidik atas persoalan masyarakat dan bangsa secara keseluruhan. Demikian juga peran guru dalam masyarakat tergantung pada gambaran masyarakat tentang kedudukan guru dan status sosialnya di masyarakat. Jadi peranan itu juga tidak terlepas dari kualitas pribadi guru yang bersangkutan serta kompetensi mereka dalam bekerja. Pada masyarakat yang paling menghargai, guru pun akan sangat sulit untuk berperan banyak dan mendapatkan kedudukan sosial yang tinggi jika, seorang guru tidak memiliki kecakapan dan kompetensi di bidangnya. Ia akan tersisih dari persaingan dengan guru-guru lainnya. Apalagi guru-guru yang tidak bisa memberikan keteladanan bagi para muridnya sudah barang tentu justru menjadi bahan pembicaraan orang banyak. Jika dihadapkan para muridnya seorang guru harus bisa menjadi teladan, ia pun dituntut hal yang sama di dalam berinteraksi dengan masyarakat sekitar.

Penghargaan atas peranan guru di negara kita bisa dibedakan menjadi dua macam.

1. Penghargaan sosial, yaitu penghargaan atas jasa guru dalam masyarakat. Penghargaan ini dilihat dari sikap sosial anggota masyarakat serta penempatan posisi guru dalam stratifikasi sosial masyarakat yang bersangkutan. Hal semacam ini akan tampak jelas kita amati pada masyarakat pedesaan yang selalu menunjukkan rasa hormat dan santun terhadap para guru yang menjadi pengajar bagi anak-anaknya. Masyarakat lebih memberi kata-kata sopan santun terhadap guru, seperti panggilan pak guru, mas guru.

2. Penghargaan ekonomis, yaitu penghargaan atas peran guru dipandang dari seberapa besar gaji yang diterima oleh guru. Dengan kondisi gaji guru-guru di Indonesia tahun 2000-an ini, tidak mungkin sejahtera dalam hal ekonomi jika hanya mengandalkan pekerjaan mengajar saja. Hal inilah yang menjadikan kurang maksimalnya peranan guru dalam menjalankan tugas mengajar, apalagi melakukan pengabdian masyarakat. (M.Rifa'I, 2011; 181).

Di dalam masyarakat, guru berperan sebagai pemimpin yang menjadi panutan atau teladan serta contoh (reference) bagi masyarakat sekitar. Mereka adalah pemegang norma dan nilai-nilai yang harus dijaga dan dilaksanakan. Hal ini dapat dilihat bahwa betapa besar ucapan guru dalam masyarakat sangat berpengaruh terhadap orang lain. Ki Hajar Dewantara menggambarkan peran guru sebagai stake holder atau tokoh panutan dengan 
ungkapan-ungkapan ing ngarso sungulodho, ing madya mangun karso, tut wuri handayani.

Di sini tampak jelas bahwa guru memang sebagai pemeran aktif, dalam keseluruhan aktivitas masyarakat secara holistik. Tentunya, para guru harus bisa memposisikan dirinya sebagai agen yang benar-benar membangun, sebagai pelaku propaganda yang bijak dan menuju ke arah yang positif bagi perkembangan masyarakat. (Karsidi, 2008; 42).

Partisipasi yang utama adalah tanggung jawab pengembangan pendidikan sebagai proses sosialisasi berapa pada orangtua dan kelompok-kelompok masyarakat yang berkepentingan. Tanggung jawab tersebut tentu mengalami dinamika, tidak pernah lepas dan mengendur. Karena paradigma tersebut telah bergeser menuju kepada peluang yang lebih bagi teraktualisasikannya kembali partisipasi masyarakat, perlu segera dilakukan pemulihan dan pengembalian tanggung jawab masyarakat terhadap pengembangan pendidikan, baik dalam skala makro maupun skala mikro. Inilah yang disebut Karsidi sebagai reaktualisasi partisipasi masyarakat karena sebenarnya yang bertanggung jawab dalam hal ini justru masyarakat. Dengan mengacu pada lingkup partisipasi masyarakat dalam pengembangan pendidikan, masyarakat harus sejak proses perencanaan, pelaksanaan, serta pemanfaatan hasil dan evaluasi.

Program-program pembelajaran di sekolah berupa desain kurikulum dan pelaksanaannya, kegiatan nonkurikuler sampai pada pengadaan kebutuhan sumber dana untuk suatu sekolah agar dapat berjalan lancar, tampak harus sudah mulai diberikan ruang partisipasi bagi pihak-pihak yang berkepentingan. Demikian pula di lembaga-lembaga pendidikan non sekolah lainnya, ruang partisipasi tersebut harus dibuka lebar agar tanggung jawab pengembangan pendidikan tidak tertumpu pada lembaga pendidikan tersebut, lebih-lebih pada pemerintah sebagai penyelenggaraan negara.

Partisipasi dan tanggung jawab negara atau pemerintah terhadap pengembangan pendidikan sebagai mana yang diamanatkan oleh UU Sisdiknas 2003 bahwa pemerintah pusat dan pemerintah daerah berhak mengarahkan, membimbing, membantu, dan mengawasi penyelenggaraan pendidikan, serta berkewajiban memberikan layanan dan kemudahan penyelenggaraan pendidikan yang bermutu bagi setiap warga negara tanpa diskriminasi. Pemerintah pusat dan daerah juga wajib menjamin tersedianya dana guna terselenggaranya pendidikan bagi setiap warga negara usia tujuh sampai usia lima belas tahun. Lebih dari itu, sebenarnya peluang bagi orangtua atau warga negara dalam kelompok masyarakat masih sangat luas.

Untuk itu, dalam kondisi kualitas layanan dan output pendidikan sedang banyak dipertanyakan mutu dan relevansinya, pemerintah seharusnya memberikan peluang yang luas bagi partisipasi masyarakat. Lebih dari itu, pemerintah perlu menyusun mekanisme sehingga orangtua dan kelompok-kelompok masyarakat dapat berpartisipasi secara optimal dalam pengembangan pendidikan di Indonesia.

Dari sini, Karsidi berkesimpulan bahwa partisipasi masyarakat dalam pendidikan sebagai berikut:

1. Adanya opini masyarakat bahwa tanggung jawab utama pembangunan (dalam bidang pendidikan) hanya terletak di tangan pemerintah, menyebabkan masyarakat hanya merasa ditempatkan sebagai bukan pemain utama dan berakibat melemahkan kemauan berpartisipasi warga dan kelompok-kelompok masyarakat dalam pengembangan pendidikan. Kondisi ini telah merugikan pengembangan pendidikan dan semakin memberatkan pemerintah sebagai penyelenggaraan negara. 
2. Perkembangan teknologi (terutama di bidang informasi) menyebabkan peranan sekolah sebagai lembaga pendidikan mulai bergeser. Di kemudian hari, sekolah tidak lagi akan menjadi satu-satunya pusat pembelajaran karena aktivitas belajar tidak lagi terbatasi oleh ruang dan waktu. Peran guru juga tidak akan menjadi satu-satunya sumber belajar karena banyak sumber belajar dan sumber informasi yang mampu memfasilitasi seseorang untuk belajar. Peranan orangtua dalam kelompokkelompok masyarakat menjadi sangat penting untuk mengisi kekosongan peran yang tidak lagi mampu diambil oleh sekolah atau lembaga pendidikan.

3. Bergesernya paradigma pembangunan sentralistik ke disentralistik telah membuka peluang yang lebar bagi teraktualisasikannya kembali partisipasi masyarakat dalam pengembangan pendidikan.

4. Orangtua dan kelompok-kelompok masyarakat harus dilibatkan dalam pengembangan pendidikan sejak dari proses perencanaan, pelaksanaan, pemanfaatan, dan hasil evaluasinya.

5. Media dan forum yang dapat dimanfaatkan untuk penyaluran partisipasi masyarakat dalam pengembangan pendidikan antara lain adalah media musyawarah dan pembentukan institusi masyarakat yang mampu menampung aspirasi masyarakat, terutama di wilayah atau komunitas tempat sekolah/lembaga pendidikan berada.

6. Diperlukan adanya peraturan perundangan yang mengatur mekanisme partisipasi masyarakat terhadap pengembangan pendidikan, baik dalam skala nasional, maupun tingkat penyelenggara pendidikan. (Karsidi, 2008; 115-116).

Partisipasi masyarakat dalam pendidikan nasional bisa dirujukkan pada UU Sisdiknas 2003 pasal 56 terkait pembentukan dewan pendidikan dan komite sekolah/madrasah, yang perincian dan jabarannya dijelaskan dengan ayat 1 sampai 4, yaitu sebagai berikut:

1. Masyarakat berperan dalam peningkatan mutu pelayanan pendidikan yang meliputi perencanaan, pengawasan, dan evaluasi program pendidikan melalui dewan pendidikan dan komite sekolah/madrasah.

2. Dewan pendidikan sebagai lembaga mandiri dibentuk dan berperan dalam peningkatan mutu pelayanan pendidikan dengan memberikan pertimbangan, arahan, dan dukungan tenaga, sarana dan prasarana, serta pengawasan pendidikan pada tingkat nasional, provinsi, dan kabupaten/kota yang tidak mempunyai hubungan hierarkis.

3. Komite sekolah/madrasah, sebagai lembaga mandiri, dibentuk dan berperan dalam peningkatan mutu pelayanan dengan memberikan pertimbangan, arahan dan dukungan tenaga, sarana dan prasarana, serta pengawasan pendidikan pada tingkat satuan pendidikan.

4. Ketentuan mengenai pembentukan dewan pendidikan dan komite sekolah/madrasah sebagaimana dimaksud pada ayat 2 , ayat 3 , dan ayat 3 diatur lebih lanjut dengan peraturan pemerintah.

\section{F. Penutup}

Masyarakat merupakan salah satu lingkungan yang mendukung pendidikan seorang individu. Karena di dalam lingkungan masyarakat inilah seorang anak belajar bersosialisasi, dan memperoleh keterampilan. Dalam lingkungan masyarakat dapat diperoleh pengetahuan dan keterampilan sekaligus, dikarenakan di dalam masyarakat terdapat sumber-sumber belajar yang banyak baik yang bersifat tersusun maupun tidak.

Kaitan masyarakat dan pendidikan dapat ditinjau dari tiga segi yaitu: 
1. Masyarakat sebagai penyelenggara pendidikan baik dilembagakan maupun tidak dilembagakan.

2. Lembaga-lembaga masyarakat atau kelompok sosial masyarakat baik langsung mau pun tidak langsung mempunyai peranan dan fungsi edukatif.

3. Dalam masyarakat tersedia berbagai sumber belajar, baik yang dirancang maupun tidak dirancang dan dimanfaatkan.

Fungsi masyarakat sebagai pusat pendidikan sangat bergantung pada taraf perkembangan dari masyarakat dan sumbersumber belajar yang tersedia di dalamnya. Lembaga-lembaga masyarakat yang mempunyai peran edukatif yang sangat besar adalah kelompok sebaya, organisasi (kepemudaan, keagamaan, sosial, kebudayaan, ekonomi, politik) dan media massa.

Sebagai bagian dari masyarakat, maka mari kita hendaknya untuk lebih meningkatkan partisipasi dan kepedulian kita terhadap pendidikan yang ada di lingkungan tempat tinggal kita. Sehingga pendidikan dapat berlangsung dengan sebaik-baiknya.

\section{DAFTAR PUSTAKA}

Agus, Bustanuddin, Agama dalam Kehidupan Manusia Pengantar Antropologi Agama, Jakarta: Raja Grafindo Persada, 2007.

Ahmadi, Abu, Sosiologi Pendidikan, Jakarta: Rineka Cipta, 2004.

Arifin, H. M, Ilmu Pendidikan, Jakarta: Bumi Aksara, 2003.

Basri, Afifudin Hasan, Kapita Selekta Pendidikan, Bandung: CV. Pustaka Setia, 2012.

Daradjat, Zakiah, Ilmu Pendidikan Islam, Jakarta: Bumi Aksara, 2009.

Gunawan, Ary. Sosiologi Pendidikan, Jakarta: Rineka Cipta, 2002.

Jalal, Abdul Fattah, Azas-asaz Pendidikan Islam, terj. Hery Noer Ali, Bandung: Diponegoro, 1988.

Karsidi, Ravik, Sosiologi Pendidikan, Surakarta: UNS Press, 2005.

Koentjaraningrat, Pengantar Ilmu Antropologi, Jakarta: Rineka Cipta, 2009.

Nata, Abudin, Kapita Selekta Pendidikan Islam, Bandung: Angkasa, 2003.

Pidarta, Made, Manajemen pendidikan Indonesia, Jakarta: Rinneka Cipta, 2004.

Sagala, Saiful, Administrasi Pendidikan Kontemporer, Bandung: Alfabeta, 2006. 
Tirtarahardja, Umar dan S.L.La. Sulo, Pengantar Pendidikan, Jakarta: Rineka Cipta, 2005.

http://gadogadozaman.blogspot.co.id/2013/06/ peran-serta-masyarakat-dalam-pendidikan.html diakses pada hari Kamis tanggal 15 Oktober 2015 pukul 10.00 WIB.

https://afidburhanuddin.wordpress.com/2013/1 2/26/pengelolaan-partisipasimasyarakat-dalam-pendidikan/ diakses pada hari Kamis tanggal 15 Oktober 2015 pukul 10.14 WIB.

https://uns.ac.id/data/sp11.pdf diakses pada hari Kamis tanggal 15 Oktober 2015 pukul 10.28 WIB 